\title{
Uwięziony w podróży*... Adama Zagajewskiego poetyckie obrazy współczesnej Italii
}

\section{Abstract \\ Trapped on a journey... Poetic images of contemporary Italy in the works of Adam Zagajewski}

The author distinguishes and analyzes those poems by Adam Zagajewski in which the poet attempted to capture and describe the atmosphere of Italian cities and towns, with their charming landscapes, nostalgic nooks and bustling arteries. His poetic eye and sound-sensitive ear are especially inspired by this kind of non-obvious beauty that is suddenly visible, in a momentary flare, often in a perception tired of wandering, but always focused on what is individual, meaningful and important. Subsequent works, along with analyzes devoted to them, were arranged in correlation with the topographic layout of the map of Italy, in line with the north-south vector (Camogli, Bogliasco, Genoa area, Ravenna, Sansepolcro, Siena, Rome, Sicily). The poet captures and preserves not only what is the most obvious, undoubtedly beautiful (such as Ravenna mosaics or paintings seen in dark museums or side chapels), but also the hustle and bustle of the capital, the stony sadness of a necropolis visited by chance, and finally the lazy peace of Italian November.

Key words: Adam Zagajewski, Italian poems, poetic images of contemporary Italy

Słowa kluczowe: Adam Zagajewski, wiersze włoskie, poetyckie obrazy współczesnej Italii

* Parafraza sformułowania pochodzącego z wiersza Adama Zagajewskiego Syrakuzy (por. Zagajewski 2005: 56).

59

Fabrica Litterarum Polono-Italica | 2021, nr 1 (3) 
Adam Zagajewski, obywatel świata, wielbiciel europejskich miast, często podejmuje próby utrwalenia w poezji klimatu włoskich miast i miasteczek, zatrzymania w wierszu urokliwych krajobrazów, nostalgicznych zaułków. Wykreowanego przez niego bohatera lirycznego możemy spotkać „w Rzymie - na Via Giulia, na Piazza Navona, w pałacu Barberini, nad Tybrem (Rzym, miasto otwarte), na plaży w pobliżu Cefalu na Sycylii (Morze), w Syrakuzach, pod murami Ortygii (Syrakuzy), na targu w Lukce (Życie nie jest snem), ale także w Paryżu - w kawiarni na Saint Lazare (Niemożliwe przyjaźnie)" (Drzewucki 2006). W jednym z wierszy zachowujących powidok prywatnych podróży poeta wspomina, dowodząc, że jego spojrzenie na Italię zawiera w sobie również głęboki ślad tego, co kulturowe: „Widziałeś Wenecję i Sienę i, na płótnach, na ulicy, / smutne młodziutkie Madonny, które chciały być / zwykłymi dziewczynami i tańczyć w karnawale" (Mów spokojniej; Zagajewski 1999: 72-73). Utrwala „wąskie uliczki Umbrii, w których [...] / zatrzymał się stary czas o smaku słodkiego wina” (Widzieć; Zagajewski 1999: 47). Echa włoskich podróży' mają w tej poezji niemal zawsze źródła bardzo prywatne, będące konsekwencją indywidualnych wypraw i pobytów, natomiast konsekwencje głęboko kulturowe. Genezę wspomnianej miłości do Włoch zdradza napisany w osobistym tonie ${ }^{2}$ list Charlesa Kennetha Williamsa, brytyjskiego poety, tłumacza wierszy Zagajewskiego na język angielski, a prywatnie przyjaciela (zmarłego w 2015 roku), w którym zawarł nadawca następujące wspomnienie:

Kolejna rzecz to osobista satysfakcja, na jaką sobie pozwalam, gdy znajduję wiersze, osadzone w miejscach, których doświadczaliśmy wspólnie podczas naszych długich spacerów w Paryżu, letnich wypraw z naszymi żonami do Włoch, południowej Francji, Szwajcarii, Grecji, Turcji, na Korsykę... Szczerze mówiąc, przeglądanie tych wierszy sprawia mi wielką frajdę [...]. Nasze podróże często prowadziły nas ku morskim brzegom, a działo się tak - jak sądzę - głównie dlatego, że są one dla Ciebie tak ważne. W czasie tych wędrówek, kiedy szukaliśmy jakiegoś miejsca do pływania, to Ty zawsze odnajdywałeś ukrytą plażę lub niemal nieosiągalną skalistą okolicę; zawsze szukałeś tych miejsc a potem płynąłeś długo swoim cierpliwym, metodycznym klasykiem, który przenosił Cię w rejony tak bardzo oddalone od brzegu, że sam nie śmiałbym się w nie zapuszczać. Później, nie jestem pewien kiedy, zdarzało się, że z tego doświadczenia wysnuwałeś jeden ze swych mocno poruszających wierszy (Williams 2015: 61-62).

1 Tematem śladów włoskich podróży w twórczości Adama Zagajewskiego zajmowała się Karolina Najgeburska. Zob. Najgeburska 2018: 205-216.

2 Opublikowany w jubileuszowej antologii, wydanej z okazji 70. urodzin poety (Czabanowska-Wróbel, red. 2015). Zob. także Kowalczyk 2015.

60

Fabrica Litterarum Polono-Italica | 2021, nr 1 (3) 
Podmiot liryki Zagajewskiego kojarzy Italię z tym, co estetycznie (i aksjologicznie) najgłębsze - z siłą natury, samoistnie przeobrażającej się w kulturę, w samorodne dzieło sztuki. Z tym, co niejednokrotnie staje się obiektem tęsknoty, sennych marzeń. W wierszu Majestat snu zdradza: „Sen jest Toskanią widzianą o świcie, / gdy smukłe drzewa piją atrament / z czarnej ziemi" (Zagajewski 1999: 15). Poeta poszukuje w miastach Italii piękna, ale i chwili wytchnienia. W wierszu Vaporetto zabiera odbiorcę w utkaną ze wspomnień, snów i marzeń podróż weneckim tramwajem wodnym, który - przekraczając granice wyznaczone przez trasę realną, zmierza dalej, przez nieodległe miejsca, aż po sensy głębsze, naddane, zawarte w odrywającej się od świata metaforze. W tej przestrzeni widać np. prześwit Burano, położonej nieopodal Wenecji starej, malowniczej wioski rybackiej, słynącej z koronkarstwa.

W kieszeni wiatrówki znajdujesz

niebieski bilet na vaporetto

(il biglietto, non cedibile).

Niebieski bilet, [...]

obiecuje ci odmianę, podróż.

Topi się lak na wspomnieniu,

[...]

Teraz może się zacząć wyprawa.

[...]

Będziesz płynął długo. Może dopłyniesz

tam, gdzie spoczywa jeż Wenecji,

woda, koronki i złoto.

Może dotrzesz tam, gdzie się wznoszą

czerwone wieże Wenecji, wierne wieże,

wieże - igły kompasu, który utonął.

(Zagajewski 1999: 38)

Podążając za myślą zawartą w wierszu, kolejne utwory (i analizy im poświęcone) uporządkowane zostały w kolejności odpowiadającej układowi topograficznemu mapy Italii, tak by czytelnik mógł wraz z „ja” lirycznym przemieszczać się z północy na południe, począwszy od malowniczych Camogli i Bogliasco, poprzez okolice Genui, Rawennę, Sansepolcro, Sienę, zatrzymując się nieco dłużej w Rzymie, by w końcu dotrzeć aż do Sycylii (Syrakuz i Noto).

61

Fabrica Litterarum Polono-Italica | 2021, nr 1 (3) 


\section{Warstwowość Camogli}

Wiersz Camogli (Zagajewski 2005: 26) utrwala obraz miasta leżącego na półwyspie Portofino, w regionie Liguria, około 20 km od Genui. Podczas jego lektury można odnieść wrażenie, że poeta poprzez rządzącą wierszem zasadę konstrukcyjną próbuje oddać dominującą cechę topograficzną Camogli - warstwowy układ miasteczka, na które składają się wielopiętrowe kamienice, wybudowane nad brzegiem morza, na skale ${ }^{3}$. Zagajewski opiera dominujący obraz poetycki na wyliczeniu, poprzedzielanym konsekwentnie powracającą konstrukcją polisyndetoniczną, pozwalającą wyobraźni czytelnika wspinać się, schodzić lub potykać się o werbalizowane w ten sposób stopnie monologu lirycznego.

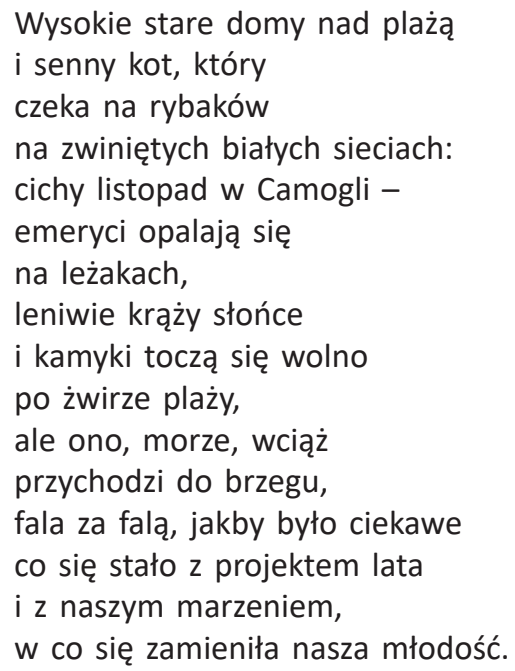

(Zagajewski 2005: 26)

Gdy skupić uwagę na budowie wiersza, na wizualnym wrażeniu wysokości, niemal strzelistości, które odnosi czytelnik spoglądający na kształt lirycznego zapisu, znajdujemy się bardzo blisko owej cechy charakterystycznej kamieniczek Camogli - zdecydowanie wysokich, co jest konsekwencją zmian dokonywanych na przestrzeni stuleci przez właścicieli. Jak zauważają autorzy poświęconych Italii blogów podróżniczych, kiedy w rodzinie przychodziło na świat dziecko lub też marynarz wracał z długiego rejsu, dobudowywano nowe pomieszczenia, a czasem i całe

3 Zob. opis Camogli na blogu That's Liguria!: https://thatsliguria.com/camogli-romantyczne-domy-zon/ [dostęp: 21.03.2020].

62

Fabrica Litterarum Polono-Italica | 2021, nr 1 (3) 
piętro4. W końcowym trójwersie utworu pobrzmiewa zaś dyskretnie przemycone nawiązanie do bogatej kolorystyki miasta, stanowiącej kolejną z jego cech charakterystycznych. Ową wyrazistość barw, ponoć ułatwiającą rybakom powroty z połowów podczas mglistej pogody5, znamionować mogą rzeczowniki „lato”, „marzenie” oraz „młodość”, w wyraźny sposób generujące skojarzenia z tym, co barwne, urokliwe. Elementem najbardziej stałym, wiecznym, choć wewnętrznie dynamicznym, okazuje się w tej przestrzeni personifikowany żywioł morski, gdyż to właśnie „ono, morze, wciąż przychodzi do brzegu, / fala za falą, jakby było ciekawe / co się stało z projektem lata / i z naszym marzeniem, / w co zamieniła się nasza młodość" (Zagajewski 2005: 26).

\section{Zaduma Bogliasco}

Żywioł morski okazuje się górować nad ludzkim również w wierszu Bogliasco: placyk przed kościołem (Zagajewski 2005: 27). Ponownie to właśnie morze stanowi tutaj ten element świata, który odczuwany jest jako najbardziej stały, wieczny, pozwalający nabrać dystansu wobec tego, co ulotne, a tym samym mniej istotne, gdyż „wieczorem powraca / tumult morza / i ten zgiełk / odsuwa w niepamięć / miniony dzień" (Zagajewski 2005: 27). Utwór oparty jest na sprzeczności semantycznej wynikającej z naprzemiennego przyspieszania i spowalniania tempa sytuacji lirycznej. Z jednej strony przeładowany jest czasownikami - i ta czynnościowość wydaje się znacząca, pozwalając poecie nie tylko zarejestrować letni klimat położonego $11 \mathrm{~km}$ od Genui, włoskiego miasta, lecz również dodać mu dynamiki - choć już po chwili wspomniana dynamizacja okazuje się zwodnicza, co rusz bowiem Zagajewski spowalnia monolog liryczny rzeczownikami sugerującymi zatrzymanie, zawieszenie, namysł. Oto: „Fotograf wywołuje filmy”, a jak wiadomo, czynność ta wykonywana być musi w odpowiednich warunkach, w ciemni, skupieniu; „kościelny przygląda się / murom i drzewom / bardzo uważnie”, który to stan także w ewidentny sposób sugeruje zatrzymanie; co więcej, zaraz potem dowiadujemy się, że „pralnia chemiczna / czyści sumienie / tego spokojnego miasteczka" (Zagajewski 2005: 27). Niemal wszystkie te sformułowania odsyłają uwagę odbiorcy w stronę pól semantycznych kojarzących się z mentalnym zatrzymaniem, spokojną refleksją. I tylko „chłopcy grają w piłkę", choć i w tym obrazie da się wyczuć nutę nostalgii, tęsknoty za tym,

4 Zob. np. That's Liguria! https://thatsliguria.com/camogli-romantyczne-domy-zon/ [dostęp: 24.03.2020].

5 Z tym też wiąże się prawdopodobnie sama nazwa Camogli, oznaczająca "dom żon” (casa delle Mogli).

63

Fabrica Litterarum Polono-Italica | 2021, nr 1 (3) 
co bezpowrotnie minione. To genialna umiejętność uchwycenia przez poetę istoty italijskich miast - gwarnej dynamiki, spokojnego rozleniwienia, a w przewidzianych zwyczajem i temperaturą porach - totalnego zatrzymania, następujących naprzemiennie i przez ową naprzemienność nierozerwalnie z sobą złączonych.

\section{Kamienny spokój Staglieno}

W utworze zainspirowanym wyprawą na znajdujący się w pobliżu centrum Genui, Monumentalny Cmentarz Staglieno ${ }^{6}$ Zagajewski udowadnia, że wiersz, nie tracąc nic ze swojej poetyckości, jest w stanie z niemal reporterską precyzją utrwalać i przechowywać funeralno-nostalgiczny klimat miejsca. W tym przypadku cechami współtworzącymi ów klimat są kolorystyka i budulec (gips i marmur), które - podobnie jak w rzeczywistej przestrzeni cmentarza - okazują się nierozerwalnie ze sobą zrośnięte.

Nie zatrzymuj się długo na tym cmentarzu gdzie wciąż jeszcze pokutuje wiek dziewiętnasty, zakurzony, pozbawiony wdzięku: przyjmą cię lekarze w gipsowych surdutach zapiętych pod szyją, w kamiennych krawatach, kamienni adwokaci z kamiennym, nieco smutnym uśmiechem (obłuda przeżyła samą siebie). Przyjmą cię ojcowie rodzin, profesorowie i dzieci, marmurowe dzieci i gipsowe psy, zawsze nienagannie posłuszne. Zobaczysz przeszłość, spotkasz twoich starszych braci, ujrzysz Pompeję, którą zatopiła szara lawa czasu.

(Zagajewski 2005: 28)

Szarość i kamienność nekropolii sygnalizuje poeta poprzez poetyckie konceptualizowanie elementów sytuacji lirycznej, przywodzących ma myśl odpowiednią

6 Otwarty w 1851 roku, który stał się miejscem pochówku znanych osobistości, pochodzących nie tylko z Genui, ale i z zagranicy. Pod względem architektonicznym łączy w sobie strukturę neoklasycznej architektury cmentarza tradycji śródziemnomorskiej ze stylem romantycznym cmentarzy Europy Północnej http://www.scoprogenova.com/pl/wycieczki-klasyczne/monu mentalny-cmentarz-staglieno [dostęp: 25.03.2020].

64

Fabrica Litterarum Polono-Italica | 2021, nr 1 (3) 
gamę barw. Obrazowanie to współtworzą więc metafory odnoszące się do czasu powstania cmentarza, jego niemal dokumentacyjnego charakteru („wciąż jeszcze pokutuje wiek dziewiętnasty, / zakurzony”, „szara lawa czasu”) oraz opisu konkretnych nagrobków („lekarze w gipsowych surdutach [...] / w kamiennych krawatach”, „kamienni adwokaci z kamiennym, nieco smutnym / uśmiechem”, „marmurowe dzieci”, „gipsowe psy"). Nad tym nieruchomym krajobrazem pobrzmiewa silna nuta melancholii, podkreślona inicjującą wiersz przestrogą („Nie zatrzymuj się długo na tym cmentarzu / [...] / Zobaczysz przeszłość, spotkasz / twoich starszych braci"). Długie przebywanie na terenie nekropolii nie służy spokojowi psychicznemu. Trzeba odpowiednio szybko wracać do życia (por. Najgeburska 2018: 212).

\section{Mozaiki Rawenny}

W innym wierszu, pochodzącym z tomu Niewidzialna ręka, możemy wraz z poetą poczuć klimat słynącej z mozaikowych technik zdobniczych Rawenny. To trzykrotnie zyskujące status stolicy miasto uwodzi poetę zanurzeniem w historii, spokojem i - często podkreślanym w obrębie monologu lirycznego - bogactwem zieleni: „Rawenna jest cicha, botaniczna. / Po płaskiej ziemi chodzą drozdy / [...] / Ta wilga śpiewała w języku bogów / [...] / Te akacje wspinały się do romańskiego sklepienia" (Zagajewski 2009: 51).

Mozaika, będąca najbardziej rozpoznawalnym symbolem Rawenny, oparta jest na wielości elementów składowych, a także na powtarzalności kształtu i formy. Właśnie ową powtarzalność wykorzystuje poeta na prawach tropu artystycznego, by wcielić się na moment w zwiedzającego miasto turystę lub przewodnika, który - stosując powtarzalne chwyty, używając wyuczonych na pamięć formuł, prowadzi odbiorcę po najważniejszych miejscach Rawenny, eksponuje jej najbardziej charakterystyczne rysy. Anaforyczny ciąg wyliczeniowy pomaga mu poradzić sobie z wielością wrażeń i miejsc godnych pokazania, nieco ograniczyć tę wielość i wyeksponować: „To małe senne miasto było kiedyś stolicą imperium. / Ten piekarz był cesarskim piekarzem. / Ten ogień płonął wysoko. / Ten krawiec pochylał się nad złotogłowiem. / Ta wilga śpiewała w języku bogów. [...] Te cegły dotykały palców. / Te palce dotykały drzew i żelaza. / Te akacje wspinały się do romańskiego sklepienia" (Zagajewski 2009: 51). Dzięki użyciu ciągu anaforycznego do tego stopnia zaciera Zagajewski granicę pomiędzy obrazem realnego świata a wizerunkiem uwiecznionym na zabytkach, że czytelnik nie może być pewien, czy liryczne „ja” relacjonuje świat realny, czy też właśnie w tym momencie, spoglądając na mozaiki, słucha przewodnika wskazującego mu widniejące na nich wzory, kształty, ornamenty. Wrażenie to

65

Fabrica Litterarum Polono-Italica | 2021, nr 1 (3) 
jest tym silniejsze, że poeta zaznacza płaskość obserwowanego obrazu: „Po płaskiej ziemi chodzą drozdy”, by zaraz potem podkreślić... „W mozaikach jeszcze się tli złoty płomień, / na pewno kiedyś zgaśnie. / Ale jedna zapałka wystarczy, / żeby go wzniecić od nowa. / Wystarczy chwila skupienia" (Zagajewski 2009: 51). Kończące ów ciąg wyliczeniowy pytanie retoryczne "Czy naprawdę?" może niepokoić, sygnalizując obawę poety "o trwałość blasku pochodzącego z mozaikowych dzieł sztuki” (Wydrycka 2013: 306), „o płomień tlący się in opere musivo” (Wydrycka 2013: 306), na co zwraca uwagę Anna Wydrycka, podkreślając, że „światło, płomień, blask ewokowane przez raweński ukryty skarb wskazują niewątpliwie tę sferę wartości, która może zostać utracona" (Wydrycka 2013: 306).

\section{Sansepolcro}

Sporą grupę wierszy w dorobku Zagajewskiego stanowią utwory odnoszące się do sfery sztuki, będące przynajmniej częściowo ekfrazami ${ }^{7}$ konkretnych przedstawień malarskich. Tak dzieje się w przypadku utworu Senza flash z tomu Pragnienie, w którym oglądany najprawdopodobniej w Museo Civico w Sansepolcro, nieopodal Arezzo, obraz Zmartwychwstanie Piera della Francesca staje się inspiracją i pretekstem do refleksji na temat sensu życia.

Senza flash! „Bez fleszu!”

(instrukcja często słyszana we włoskich galeriach)

Bez płomienia, bez nocy bezsennych, bez żaru,

bez łez, bez wielkiej namiętności, bez przekonania, tak będziemy żyli; senza flash.

Spokojnie i miarowo, posłusznie i sennie, dłonie poplamione czarną farbą gazet codziennych, twarze tłuste od kremu; senza flash.

Uśmiechnięci turyści w bardzo czystych koszulach, Herr Lange i Miss Fee oraz Monsieur et Madame Rien wejdą do muzeum; senza flash.

Staną przed obrazem Piero della Francesca, na którym

Chrystus, prawie obłąkany, wynurza się z grobu, zmartwychwstały, wolny; senza flash.

7 Na temat odmian ekfrazy zob. Gogler 2004: 137-152; Dziadek 2002: 136-151; Dziadek 2000: $141-151$.

66

Fabrica Litterarum Polono-Italica | 2021, nr 1 (3) 
I może wtedy stanie się coś nieprzewidzianego:

poruszy się serce, ukryte pod gładką bawełną,

zapadnie cisza, błyśnie flesz.

(Zagajewski 1999: 21)

Następująco o utworze tym pisał Tadeusz Sobolewski: „W jednym z piękniejszych wierszy Zagajewskiego napis "senza flash « we włoskim muzeum - zakaz używania fleszu - staje się metaforą spłyconej wrażliwości" (Sobolewski 2015: 95). Zagajewski błysk flesza, zakazywany w tytułowym Senza flash, zestawia z błyskiem sygnowanym przez pojęcia takie, jak „płomień”, „żar”, „wielka namiętność”, konkretyzującym aksjologiczną lukę, wiersz rozpoczyna się bowiem od antycypacji opartej na silnie wybrzmiewającym wyliczeniu braku, jaki doskwiera refleksyjnej jednostce. „Bez płomienia, bez nocy bezsennych, bez żaru, / bez łez, bez wielkiej namiętności, bez przekonania, / tak będziemy żyli" (Zagajewski 1999: 21) - przepowiada liryczne „ja”, stając w obronie błysku, ale nie tego dosłownego, równoznacznego z przebłyskiem technologii, lecz mentalnego, który utożsamić można z wywołanym przez zachwyt dziełem sztuki nagłym ukłuciem religijności, epifanią sacrum, tęsknotą za transcendencją, szczęściem wynikłym z przeżywania chwili wyjętej ze sfery zwyczajności.

W wierszu pojawia się odniesienie do fresku z ok. 1463 roku, określanego często najwspanialszym obrazem świata (takim mianem w swoich esejach z podróży określił go Aldous Huxley). Dzieło - z uwagi na zainteresowania twórcy - emanuje symbolami i figurami matematycznymi. Namalowane zostało w kwadracie, choć jego układ kompozycyjny oparty jest na trójkącie. Podzielone horyzontalnie na dwie części - należący do martwych, śpiących, nieświadomych - dół oraz górę przeznaczoną dla tego, co żyje, okazuje się inspirujące również, gdy „czytać” je, podążając od strony lewej ku prawej (świat martwy budzi się wtedy do życia, zmartwychwstaje wraz z umieszczonym w centrum Chrystusem). Geometryczny kształt grobowca symbolizuje ołtarz, nawiązując jednocześnie do oznaczającej święty grób dawnej nazwy rodzinnego miasteczka artysty - Borgo San Sepolcro. W postaci jednego ze strażników - wspierającego głowę na chorągwi Chrystusa - uwiecznił artysta autoportret (gest ten stanowi wyraz jego stosunku do wiary). Inny ze strażników opiera ramię o leżący $\mathrm{w}$ rogu przedstawienia skalny głaz, mogący symbolizować (1) kamień węgielny, na którym w X wieku pielgrzymi Arcanus i Aegidius powracający z relikwiami Krzyża Świętego i kamieniem z Ziemi Świętej zbudowali miasto, (2) stanowić nawiązanie do zawartych w Księdze Psalmów słów „Kamień odrzucony przez budujących stał się kamieniem węgielnym” (3) albo też, zgodnie z Escarpitowską zasadą podatności dzieła na twórczą zdradę, całkiem wkraczając w kontekst współczesności, przypominać o wydarzeniu z 1944 roku, kiedy to alianckie wojska zdobywały Monte Cassino, a angielski oficer Tony Clarke, wykształcony humanista 
znający umiejscowienie dzieła, narażając się na sąd wojenny, nie wykonał rozkazu zbombardowania Sansepolcro, w którym ukrywali się niemieccy żołnierze (z tego właśnie powodu jedna z głównych ulic miasta nosi imię Tony’ego Clarke’a). Obraz ten uchronił więc miasto przed bombardowaniem, które najprawdopodobniej obróciłoby je w ruinę. To tylko część symbolicznych znaczeń zakodowanych we fresku Piera della Francesca (na podstawie: Farthing, red. 2008: 97; Montowski 2010; Cieślak 2013; Białkowska 2014).

\section{Brązowe miasto drżące w upale. Siena}

W wierszu Czerwiec w Sienie (Zagajewski 2009: 27) poeta próbuje uchwycić nie tylko klimat lata, ale i nastrój miejsca. By osiągnąć ten efekt, stosuje znaczące odwrócenie: oto personifikowana przyroda przejmuje cechy ludzkie („Lato krzyczało głośno"), podczas gdy ludzie - przeciwnie - nieruchomieją, a nawet można by rzec - rozpływają się w upale, tracąc kontury. Ich granice zacierają się („Zakochani zrośnięci z sobą na ławkach obliczali [...] / przyszłe zyski i straty”, „Suche usta czekały na deszcz"). Powietrze drży z upału, a obrazowanie miasta, mimo metaforyzacji, jest w pewnym stopniu realistyczne, szczególnie jeśli chodzi o akcentowanie tych cech, które zdają się być dominującymi. Pisze Zagajewski: „brązowe miasto drżało” (Zagajewski 2009: 27).

...we shall never be in touch with something greater than ourselves

Richard Rorty

Zdarzały się dni płaskie, kiedy rządziła wątpliwość, dni oczywistej zgody.

Lato krzyczało głośno jak sprzedawcy warzyw na targu w Paryżu.

Zakochani zrośnięci z sobą na ławkach obliczali już przyszłe zyski i straty,

miesiące szczęścia i niezgody.

Czerwiec w Sienie: na każdym placyku chłopcy ćwiczyli grę na werblach przed palio -

brązowe miasto drżało, jak armia przed bitwą.

Suche usta czekały na deszcz.

(Zagajewski 2009: 27)

68

Fabrica Litterarum Polono-Italica | 2021, nr 1 (3) 


\section{W reporterskim teleobiektywie wiersza. Rzym}

Stolicę Italii reprezentuje w poezji autora Ziemi ognistej kilka wierszy, m.in. Rzym, miasto otwarte z tomu Anteny (Zagajewski 2005: 9-10) oraz Powołanie Mateusza ze zbioru Prawdziwe życie (Zagajewski 2019: 42-43). Pierwszy stanowi zapowiedź drugiego. Co więcej, i jeden, i drugi zawiera wyczuwalne nawiązania do sfery prywatności.

W utworze Rzym, miasto otwarte ${ }^{8}$ wczesnowiosenny obraz stolicy współtworzą cztery płaszczyzny: obraz miejskiego pośpiechu i zgiełku, głos dzieł sztuki, malowideł oraz miejsc kultu, chaos planu zdjęciowego kręconego nieopodal filmu, a także przebijający przez to wszystko ślad sprzeczki z ukochaną. Dzięki takiemu nałożeniu na siebie czterech płaszczyzn utwór przestaje być jedynie wspomnieniową migawką z podróży, stając się reportażowym dowodem, zdolnym utrwalać świat w postaci, w jakiej wydarzał się przed oczyma poety. Zarejestrowanemu obrazowi brak jednak spójności, gdyż tym, co najbardziej doskwiera lirycznemu „ja”, okazuje się brak porozumienia. „Dlaczego przestaliśmy rozmawiać?” - zapytuje na wstępie wiersza. "Chciałbym dzisiaj zobaczyć twoje oczy bez gniewu" - wyznaje chwilę później. „Wybacz mi moje milczenie. Wybacz mi twoje milczenie” - prosi w finale, dodając afirmatywnie: „Spotkamy się na Piazza Navona, być może, jeśli zechcesz”.

Marcowy dzień, kiedy drzewa są jeszcze nagie; platany cierpliwie czekają na zielony żar liści.

Świątynie pokryte kurzem; cynober i ochra, siena i bordeaux, szerokie plamy cynamonu

Dlaczego przestaliśmy rozmawiać?

W pałacu Barberini piękny Narcyz wpatruje się w swoją twarz, martwą.

Brązowe miasto, które bez przerwy powtarza: mi dispiace.

Brązowe miasto, do którego przyjeżdżają zmęczeni greccy bogowie

jak urzędnicy z prowincji

Chciałbym dzisiaj zobaczyć twoje oczy bez gniewu.

Brązowe miasto, rosnące na wzgórzach.

Wiersze to krótkie tragedie, przenośne jako radio tranzystorowe,

8 Tytuł wiersza stanowi aluzję do włoskiego dramatu wojennego z 1945 roku, wyreżyserowanego przez Roberta Rosselliniego, którego akcja toczy się podczas niemieckiej okupacji Rzymu w 1944 roku. Utwór Zagajewskiego i film mają ten sam tytuł. Być może obejrzany obraz filmowy wywołał skojarzania ze wspomnieniem rzymskiego pobytu. Oba teksty kultury łączy również realizm przedstawienia. Film Rosselliniego, nominowany do Oskara, uważany jest za dzieło otwierające okres neorealizmu we włoskim kinie, natomiast wiersz Zagajewskiego opiera się na dość realistycznej, niemal reporterskiej próbie odtworzenia obrazu i klimatu miasta.

69

Fabrica Litterarum Polono-Italica | 2021, nr 1 (3) 
Paweł leży na ziemi, jest noc i pochodnia i zapach smoły. W kawiarniach pośpieszne spojrzenia, ktoś krzyczy, na stole leży stosik monet. Dlaczego tak? Dlaczego nie? W huku samochodów i skuterów, w huku wydarzeń. Poezja często znika i zostają zapałki. Nad Tybrem biegną dzieci w śmiesznych szkolnych pelerynach z początku wieku; obok kamery i reflektory. Biegną dla filmu, nie dla ciebie. Dawid wstydzi się zabójstwa Goliata. Wybacz mi moje milczenie. Wybacz mi twoje milczenie. Miasto pełne posągów, tylko fontanny śpiewają. Zbliżają się święta, wkrótce poganie wejdą do kościołów. Via Gulia: kwiaty magnolii strzegą swego sekretu.

Za minutę światła płacisz zaledwie pięćset lirów, które wrzucasz do czarnej skrzynki.

Spotkamy się na Piazza Navona, być może, jeśli zechcesz. Mateusz wciąż zadaje sobie pytanie: czy to naprawdę ja zostałem powołany, by stać się człowiekiem?

(Zagajewski 2005: 9)

Wspomniane, prywatne nieporozumienie rzutuje na postrzeganie świata. Dosięga nawet odniesień do sfery dzieł sztuki, które zwykle w wierszach Zagajewskiego nie podlegają wartościowaniu, stanowiąc dla poety - można by rzec - sacrum bezwzględne, bezdyskusyjne. Tu jednak twarz Narcyza wydaje się podmiotowi wypowiadającemu martwa, greccy bogowie - zmęczeni, „Wiersze to krótkie tragedie”, zresztą „Poezja często znika i zostają zapałki”, przedstawieni na płótnach biblijni bohaterowie żałują swoich czynów („Dawid wstydzi się zabójstwa Goliata”), a miasto okazuje się „pełne posągów”, a więc również częściowo martwe. Także właściwa sfera sacrum nie zdołała się oprzeć mentalnemu cieniowi rzucanemu przez wewnętrzny niepokój lirycznego „ja”: „Świątynie pokryte kurzem”, bohater obrazu Caravaggia Nawrócenie Świętego Pawła - wciąż jeszcze „leży na ziemi, jest noc i pochodnia i zapach smoły”, „Zbliżają się święta, wkrótce poganie wejdą do kościołów”. O głęboko prywatnym charakterze zarejestrowanego doświadczenia świadczyć może również fragment „Nad Tybrem biegną dzieci w śmiesznych szkolnych pelerynach / z początku wieku; / obok kamery i reflektory. Biegną dla filmu, nie dla ciebie", stanowiący dyskretne nawiązanie do wczesnego etapu kariery zawodowej towarzyszki życia poety.

Omawiany wiersz, za sprawą aluzji do obrazów Caravaggia Nawrócenie Świętego Pawła oraz Powołanie Mateusza („Mateusz wciąż zadaje sobie pytanie: czy to naprawdę ja zostałem / powołany, by stać się człowiekiem?”), stanowi przejście do 
kolejnego rzymskiego, dużo późniejszego wiersza, pt. Powołanie Mateusza (Zagajewski 2019: 42-43), opatrzonego przypisem: „W bocznej kaplicy kościoła San Luigi dei Francesi w Rzymie znajdują się trzy arcydzieła Caravaggia; żeby je oświetlić, trzeba wrzucić monetę do automatu" (wiersz poprzedzony został mottem nawiązującym do opartego na podobnej zasadzie konstrukcyjnej utworu Wisławy Szymborskiej pt. Pogrzeb. Można byłoby wskazać również analogię do utworu Stanisława Barańczaka Garden party). I oto znów zabiera nas Zagajewski w reportażową podróż w sam środek akcji dziejącej się w konkretnym miejscu, w konkretnym czasie, przy udziale konkretnych uczestników - odwiedzających konkretną świątynię, którzy zdecydowali się obejrzeć konkretny obraz konkretnego artysty, których reakcjom przysłuchuje się niemy świadek, ukryty przed ich oczyma w mroku świątyni. Przy czym granica pomiędzy „przysłuchuje się” a „podsłuchuje” okazuje się dość chybotliwa. Urywki głosów wyrażających zachwyt kontaktem z arcydziełem mieszają się z głosami będącymi dowodem małostkowego oburzenia formą owego kontaktu, dociekliwością szczegółów, wyrazem pośpiechu, zniecierpliwienia, jednym słowem - głosami tworzącymi zakłócenia, szumy sytuacyjne. A wszystko to układa się w wiarygodny foniczny zapis atrakcyjnego kulturowo i turystycznie miejsca.

Ksiqqdz istny Belmondo

Wisława Szymborska Pogrzeb

- Spójrz na jego rękę, na dłoń, jak dłoń pianisty

- Ale przecież ten stary nic nie może widzieć

- Jeszcze czego, płacić w kościele

- Mamo, boli mnie głowa

- Ciemne tło, figury ludzkie mocno zindywidualizowane

- Bardzo proszę trochę ciszej, nie można się skupić

- Te monety na stole, ciekawe ile są warte

- Chyba są srebrne, tak, na pewno, z domieszką czegoś

- Boże, jakie to piękne

- Który to jest właściwie Mateusz, ten młody czy ten stary?

- Mało co nas nie okradli dzisiaj w metrze

- Zobacz, tam jest krzyż na oknie

- Znowu zgasło

- A z lewej strony taka czarna ściana, jakby koniec świata

- Masz jeszcze euro albo pięćdziesiąt centów?

- Na pewno nie ten młody

- Niedługo będą zamykali, pospiesz się

- Ciekaw jestem, na ile ubezpieczyli te obrazy

- Jezus jest w cieniu a jednak jego twarz jest jasna

- Ja już idę, poczekam na zewnątrz

- Dlaczego nikt też go nie pilnuje?

71

Fabrica Litterarum Polono-Italica | 2021, nr 1 (3) 
- Oni żyją w półmroku i nagle przychodzi światło

- I zaraz gaśnie

* W bocznej kaplicy kościoła San Luigi dei Francesi w Rzymie znajdują się trzy arcydzieła Caravaggia; żeby je oświetlić, trzeba wrzucić monetę do automatu.

(Zagajewski 2019: 42-43)

Poprzez tę kakofonię głosów przebija często powracająca w wierszach Zagajewskiego refleksja na temat wiecznego zmagania się ciemności ze światłem ${ }^{9}$. Zmagania te również i w tym wierszu, poza znaczeniem dosłownym (odnoszącym się do sytuacji spoglądania na ciemny obraz, który - by stać się dla patrzącego widocznym - musi zostać oświetlony), zyskuje wymiar metaforyczny, dotykający zderzenia sacrum z profanum, a także blasków i cieni, z których składa się ludzkie życie („Ciemne tło”, „Znowu zgasło”, „A z lewej strony taka czarna ściana, jakby koniec świata”, „I zaraz gaśnie”, „Jezus jest w cieniu a jednak jego twarz jest jasna”, „Oni żyją w półmroku i nagle przychodzi światło”; Zagajewski 2009: 51). Wspomniana reportażowość pozwala Zagajewskiemu ukazać prawdziwy obraz świata, realny klimat miejsca, na który - poza aurą zabytków, sacrum przestrzeni, duchem miejsca/genius loci - składa się też - czasem dość barbarzyński w wyrazie - zgiełk zwykłego świata.

\section{Samotność Syrakuz}

W wierszu Syrakuzy (Zagajewski 2005: 56) dochodzi do interesującego odwrócenia perspektywy. Prawdziwym bohaterem lirycznym okazuje się tytułowe miasto, niepowtarzalne, „o najpiękniejszym imieniu”, osobne - „porzucone na skraju kontynentu".

Miasto o najpiękniejszym imieniu, Syrakuzy;

o cienistym antyku twoich zaułków nie pozwól

mi zapomnieć, ani o twoich wydętych balkonach,

które były niegdyś klatkami hiszpańskich dam,

ani o tym, jak morze uderza o mury Ortygii.

9 Owo zmaganie się wyeksponowane zostało m.in. w tytule przywoływanej już wcześniej, jubileuszowej monografii zbiorowej, wydanej z okazji 70. urodzin poety. Zob. Czabanowska-Wróbel, red. 2015.

72

Fabrica Litterarum Polono-Italica | 2021, nr 1 (3) 
Platon poniósł tu porażkę, ledwie uszedł z życiem, cóż mówić o nas, nierealnych turystach.

Twoja katedra urosła na greckiej świątyni

i rośnie dalej, ale bardzo powoli,

jak ciężkie prośby biedaków i wdów.

O północy łodzie rybackie, świecące

ostrym światłem, dopominają się o modlitwę

za zaginionych i samotnych, za ciebie, miasto porzucone na skraju kontynentu, i za nas, uwięzionych w podróży.

(Zagajewski 2005: 56)

Chybotliwy (wahający się pomiędzy singularis a pluralis, najczęściej kryjący się za zbiorowością) podmiot wypowiadający, przynależny do rzeszy „nierealnych turystów", jest świadom swej niestabilności względem wiecznego, kulturowo wielowarstwowego miasta, którego zaułki swą historią sięgają antyku. Odstające od tego wielowiekowego tła, tranzytywnie przepływające masy turystów „uwięzionych w podróży”, potrzebujących podniet i kontaktu ze śladami kultury, znajdują się zdaniem poety - w sytuacji analogicznej do Syrakuz, miasta o bogatej historii, lecz odosobnionego i tak samo potrzebującego modlitwy.

\section{Noto. Żółte miasto po katastrofie}

W wierszu Noto (Zagajewski 2005: 49) upamiętnił poeta włoskie miasteczko, dwukrotnie doświadczone katastrofą: po raz pierwszy w roku 1693, kiedy na skutek silnego trzęsienia ziemi zostało całkowicie zniszczone, oraz w roku 1996, gdy w konsekwencji błędów popełnionych podczas renowacji oraz zaniedbań z lat wcześniejszych miał miejsce kolejny kataklizm - zawaliła się kopuła katedry wraz z fragmentami sklepienia naw: głównej i południowej. Po pierwszym, dramatycznym zniszczeniu miasto zostało odbudowane w nowym miejscu, $8 \mathrm{~km}$ dalej, jako realizacja „miasta idealnego”, inspirowanego architekturą Wiednia i Paryża. (Ruiny pierwotnego miasta, pod nazwą Noto Antica, można oglądać do dziś). Nowa przestrzeń miejska - zgodnie z ideą architektonicznego baroku - miała odwzorowywać strukturę społeczną: na górze ulokowane zostały pałace arystokracji, w centrum dolnej części - katedra postrzegana jako symbol życia religijnego, natomiast peryferia przeznaczone były dla biedoty. Zapewne właśnie tę zamierzoną idealność koncepcji podkreśla poeta słowami: „Noto, miasto baroku gdzie nawet / stajnie

73

Fabrica Litterarum Polono-Italica | 2021, nr 1 (3) 
i altany są barokowe", natomiast mieszkańców ukazuje jako ubezwłasnowolnionych przez nudę: „Po południu miejscowi młodzieńcy / zbierają się na głównej ulicy // i z nudów gwiżdżą / jak drozd w niewoli".

Podróżnicy opisujący Noto podkreślają w swoich relacjach dwie dominujące cechy miasteczka: niemal namacalne doznanie ciężaru kamienia, z którego wzniesiona została replika miasta, konkretyzujące się we wrażeniu masywności oraz jego ciepłą kolorystykę, będącą konsekwencją użycia jako materiału budowlanego żółtawego tufu, który pod wpływem wędrówki promieni słońca zmienia barwę, balansując pomiędzy miodowo-żółtą a różową.

Noto, miasto które byłoby doskonałe

gdybyśmy umieli mocniej wierzyć.

Noto, miasto baroku gdzie nawet

stajnie i altany są barokowe.

Kopuła katedry zawaliła się niestety

i dźwigi budowlane stoją przy niej

jak lekarze w szpitalu

przy łóżku obłożnie chorego.

Po południu miejscowi młodzieńcy

zbierają się na głównej ulicy

i z nudów gwiżdżą

jak drozd w niewoli.

To miasto jest zbyt doskonałe

dla swoich mieszkańców.

(Zagajewski 2005: 49)

Obecnie katedra znajdująca się w centrum Noto jest odbudowana, a miasto w 2002 roku zostało wpisane na listę światowego dziedzictwa UNESCO, jednak w wierszu Zagajewskiego zostało upamiętnione właśnie w momencie procesu jej odbudowy: „Kopuła katedry zawaliła się niestety / i dźwigi budowlane stoją przy niej // jak lekarze w szpitalu / przy łóżku obłożnie chorego" (Zagajewski 2005: 49) pisze poeta.

Barbara Toruńczyk, analizując twórczość Adama Zagajewskiego, podkreśla, iż poeta „Zamierza utrwalić w poezji świat, o którym wie, że jest przemijający, a zarazem odwieczny i podległy ciągłym metamorfozom. Opisać go takim, jaki jest -

74

Fabrica Litterarum Polono-Italica | 2021, nr 1 (3) 
okaleczony, znikliwy, nieogarniony, piękny. Dostępny tylko w okamgnieniu, kiedy spojrzeniu objawia się ukryty ład, odbity w cichym trwaniu rzeczy lub twarzach przechodniów" (Toruńczyk 2015: 31). Takie zapewne założenia przyświecały Zagajewskiemu w trakcie pisania „wierszy włoskich”, temu też miała służyć tak często uruchamiana w obrębie monologu lirycznego reportażowość. Jego poetyckie oko i wyczulone na dźwięki miejsca ucho szczególnie inspiruje ten rodzaj nieoczywistego piękna, które uwidacznia się nagle, w chwilowym rozbłysku rozpraszającego mrok światła, pomimo czegoś, często w percepcji zmęczonej wędrówką, lecz zawsze skupionej na tym, co jednostkowe, znaczące, istotne. Dlatego właśnie poeta utrwala i zatrzymuje nie tylko to, co najbardziej oczywiste, bezsprzecznie piękne (jak mozaiki Rawenny lub oglądane w ciemnych muzeach czy bocznych kaplicach obrazy), ale też zgiełk stolicy, kamienny smutek odwiedzonej przypadkiem nekropolii, w końcu leniwy spokój włoskiego listopada. W tak powstałych mozaikach pamięci „jeszcze się tli złoty płomień, / na pewno kiedyś zgaśnie. / Ale jedna zapałka wystarczy, / żeby go wzniecić od nowa. / Wystarczy chwila skupienia [...]" (Zagajewski 2009: 51).

\section{Bibliografia}

Białkowska Monika (2014): Święci malowani. Najwspanialszy obraz świata. „Przewodnik Katolicki", $\mathrm{nr}$ 16. Online: https://www.przewodnik-katolicki.pl/Archiwum/2014/ Przewodnik-Katolicki-16-2014/Archidiecezja-Gnieznienska/Swieci-malowani-Naj wspanialszy-obraz-swiata [dostęp: 17.07.2020].

Cieślak Stanisława (2013): Najwspanialszy obraz świata - „Zmartwychwstanie” Piera della Francesca. Online: http://edusens.blogspot.com/2013/03/najwspanialszy-obraz-swiata.html [dostęp: 17.07.2020].

Czabanowska-Wróbel Anna, red. (2015): I cień i światło... O twórczości Adama Zagajewskiego. Kraków.

Drzewucki Janusz (2006): „Życie silniejsze niż nicość”. O „Antenach” Adama Zagajewskiego. Online: https://culture.pl/pl/artykul/zycie-silniejsze-niz-nicosc-janusz-drzewucki-o-antenach-adama-zagajewskiego-tworczosc-marz [dostęp: 24.08.2020].

Dziadek Adam (2000): Problem "ekphrasis" - dwa "Widoki Delft" (Adam Czerniawski i Adam Zagajewski). „Teksty Drugie”, nr 4.

Dziadek Adam (2002): Relacja tekst - obraz. Próba charakterystyki typologicznej. W: Dwudziestowieczna ikonosfera $w$ literaturach europejskich. Wizualizacja $w$ literaturze. Red. B. Tokarz. Katowice.

Farthing Stephen, red. (2008): 1001 obrazów, które warto w życiu zobaczyć. Warszawa. Foucault Michel (2005): Inne przestrzenie. Przeł. A. Rejniak-Majewska. „Teksty Drugie”, nr 6.

75

Fabrica Litterarum Polono-Italica | 2021, nr 1 (3) 
Gogler Paweł (2004): Kłopoty z ekfrazq. „Przestrzenie Teorii”, nr 3-4. Online: http:// www.scoprogenova.com/pl/wycieczki-klasyczne/monumentalny-cmentarz-staglieno [dostęp: 17.07.2020].

Kowalczyk Janusz R., (2015): I cień i światło... O twórczości Adama Zagajewskiego. Red. A. Czabanowska-Wróbel. Kraków 2015. Online: https://culture.pl/pl/dzielo/i-cien-i-swiatlo-na-jubileusz-adama-zagajewskiego [dostęp: 20.06.2020].

Montowski Michał (2010): Jest taki obraz. Online: https://www.polskieradio.pl/24/290/ Artykul/ 188136,Zmartwychwstanie-w-Borgo-San-Sepolcro [dostęp: 17.07.2020].

Najgeburska Karolina (2018): „Słodycz Italii, słodycz miasteczek Toskanii” - podróże włoskie Adama Zagajewskiego. „Anthropos?”, nr 27.

Sobolewski Tadeusz (2015): Projekt poezji niemożliwej. W: I cień i światło... O twórczości Adama Zagajewskiego. Red. A. Czabanowska-Wróbel. Kraków.

That's Liguria! https://thatsliguria.com/camogli-romantyczne-domy-zon/ [dostęp: 24.03.2020].

Toruńczyk Barbara (2015): Czytajq̨c Adama Zagajewskiego. W: I cień i światło... O twórczości Adama Zagajewskiego. Red. A. Czabanowska-Wróbel. Kraków.

Williams Charles Kenneth (2015): Drogi Adamie. W: I cień i światło... O twórczości Adama Zagajewskiego. Red. A. Czabanowska-Wróbel. Kraków.

Wydrycka Anna (2013): Rawenna „snem malowana”. O kreacyjnych i onirogennych właściwościach Miejsca. „Białostockie Studia Literaturoznawcze”, nr 4.

Zagajewski Adam (1999): Pragnienie. Kraków.

Zagajewski Adam (2005): Anteny. Kraków.

Zagajewski Adam (2009): Niewidzialna ręka. Kraków.

Zagajewski Adam (2019): Prawdziwe życie. Kraków.

\section{Abstract \\ Intrappolato in un viaggio... Le immagini poetiche dell'Italia contemporanea di Adam Zagajewski}

L'autore distingue e analizza queste poesie di Adam Zagajewski in cui il poeta ha cercato di catturare l'atmosfera delle città e dei paesi italiani, con i loro paesaggi affascinanti, i vicoli nostalgici, ma anche le metropoli frenetiche. Il suo occhio poetico e il suo orecchio sensibile al suono sono particolarmente ispirati da questo tipo di bellezza non evidente che è improvvisamente visibile, in un lampo momentaneo, spesso in una percezione stanca dal viaggio, ma sempre concentrata su ciò che è individuale, significativo e importante. I lavori successivi, insieme alle analisi ad essi dedicate, sono stati disposti in correlazione con il tracciato topografico della carta d'Italia, in linea con il vettore nord-sud (Camogli, Bogliasco, dintorni di Genova, Ravenna, Sansepolcro, Siena, Roma, Sicilia). Il poeta coglie e conserva non solo ciò che è più evidente e indubbiamente bello (come mosaici di Ravenna o dipinti visti nei musei bui o cappelle laterali),

76

Fabrica Litterarum Polono-Italica | 2021, nr 1 (3) 
ma anche il trambusto della capitale, la tristezza fredda di una necropoli visitata per caso, e infine la pigra pace del novembre italiano.

Parole chiave: Adam Zagajewski, poesie italiane, immagini poetiche dell'Italia contemporanea 